\title{
Apoptotic gene expression in melanoma cells treated with kaurenic acid
}

\author{
María B Rivero', Hernán J Mendoza ${ }^{1 *}$, Miguel AChiurillo', Miriam C Sosa-Seguera² \\ From Beyond the Genome 2012 \\ Boston, MA, USA. 27-29 September 2012
}

Terpenoids have been described as pharmacologically active substances. Antibacterial, antifungal, anti-inflammatory activities and cytotoxicity against cancer cell lines are some of the biological effects described for these compounds [1-4]. Kaurenic acid is a diterpene isolated from the aerial parts of Espeletia semiglobulata (Compositae) and its antitumor effect via apoptosis and necrosis against melanoma cells in animal models has been described [5]. The present study researches the molecular mechanism for this anti-melanoma effect on cells inoculated in mice. One hundred thousand cells of melanoma B16F1 were used for inoculation in fifteen male, $20 \mathrm{~g}$ weight C57BL/6 mice. There were three groups of five mice each: group $\mathrm{A}$ was treated for 21 days with saline solution $(0.009 \% /$ day); group B was treated for 21 days with Taxol $(14.5 \mathrm{mg} / \mathrm{kg} /$ week); and group $\mathrm{C}$ was treated with kaurenic acid for 21 days $(1 \mathrm{mg} / \mathrm{kg} /$ day). Two animals in group $\mathrm{C}$ died during the treatment. The expression of genes for proteins Bcl-2, Bax- $\alpha$, Bcl-xL, c-Myc, P53, ICE (caspase 1), ICH1 (caspase 2), CPP32 (caspase 3), Apa F1 (activator), TNF- $\alpha$, eNOS, Il1- $\beta$, iNOS, nNOS, Flice (caspase 8), MCH6 (caspase 9) involved in different apoptotic pathways, was qualitatively assessed by using Multiplex PCR Maxim Biotech Inc. Kits for Mouse Apoptotic Genes, with GAPDH and $18 \mathrm{~S}$ as internal controls in cDNA synthesized by Trizol method [6]. Each PCR was repeated twice in the same conditions for each sample. Amplification products were visualized in agarose gels cored with ethidium bromide and illuminated with ultraviolet light. The results showed that there was no expression of $B c l-x L$ in any of the animals from groups B and C. Furthermore, there was no expression of $i N O S, n N O S$ and $e N O S$ in samples from group C. Other evaluated genes were present in all groups.

'Laboratorio de Genética Molecular, Yunis-Turbay Departamento de Ciencias Funcionales Medicina, Universidad Centrooccidental Lisandro Alvarado, Venezuela

Full list of author information is available at the end of the article
The alteration in the expression of the $B c l-x L$ gene (antiapoptotic protein) and nitric oxide family proteins could be crucial events for the anti-melanoma effect. Kaurenic acid could offer potential usefulness as an agent for therapy of this cancer.

\section{Acknowledgements}

Thanks to Alfredo Usubillaga for providing kaurenic acid and to Peter Taylor for tumor cells.

\section{Author details}

'Laboratorio de Genética Molecular, Yunis-Turbay Departamento de Ciencias Funcionales Medicina, Universidad Centrooccidental Lisandro Alvarado, Venezuela. ${ }^{2}$ Unidad de Farmacoiogía Experimental, Departamento de Ciencias Funcionales Medicina, Universidad Centrooccidental Lisandro Alvarado, Venezuela.

Published: 1 October 2012

\section{References}

1. Chao KP, Hua KF, Hsu HY, Su YC, Chang ST: Anti-inflammatory activity of sugiol, a diterpene isolated from Calocedrus formosana bark. Planta Med 2005, 71:300-5

2. Davino SC, Giesbrecht AM, Rogue NF: Antimicrobial activity of kaurenoic acid derivatives substituted on carbon-15. Braz J Med Biol Res 1989, 22:1127-9.

3. Ohkoshi E, Kamo S, Makino M, Fujimoto Y: ent-Kaurenoic acids from Mikania hirsutissima (Compositae). Phytochemistry 2004, 65:885-90.

4. Ohkoshi E, Makino M, Fujimoto Y: Studies on the constituents of Mikania hirsutissima (Compositae). Chem Pharm Bull (Tokyo) 1999, 47:1436-8.

5. Son $\mathrm{K}$, Oh H, Choi S, Han D, Kwon B: Anti-tumor abietane diterpenes from the cones of Sequoia sempervirens. Bioorg Med Chem Lett 2005, 15:2019-21.

6. Sosa-Sequera M, Chiurillo M, Moscoso J, Dolinar J, Suarez O, Neira N, Mendoza H, Rivero M: Kaurenic acid: evaluation of the in vivo and in vitro antitumor activity on murine melanoma. Indian J Pharmacol 2011, 43:683-8.

7. Chomczynski P, Sacchi N: Single-step method of RNA isolation by acid guanidinium thiocyanate-phenol-chloroform extraction. Anal Biochem 1987, 162:156-9.

doi:10.1186/1753-6561-6-S6-P45

Cite this article as: Rivero et al:: Apoptotic gene expression in melanoma cells treated with kaurenic acid. BMC Proceedings 2012 6(Suppl 6):P45.

\section{() Biomed Central}

(C) 2012 Rivero et al; licensee BioMed Central Ltd. This is an Open Access article distributed under the terms of the Creative Commons Attribution License (http://creativecommons.org/licenses/by/2.0), which permits unrestricted use, distribution, and reproduction in any medium, provided the original work is properly cited. 